


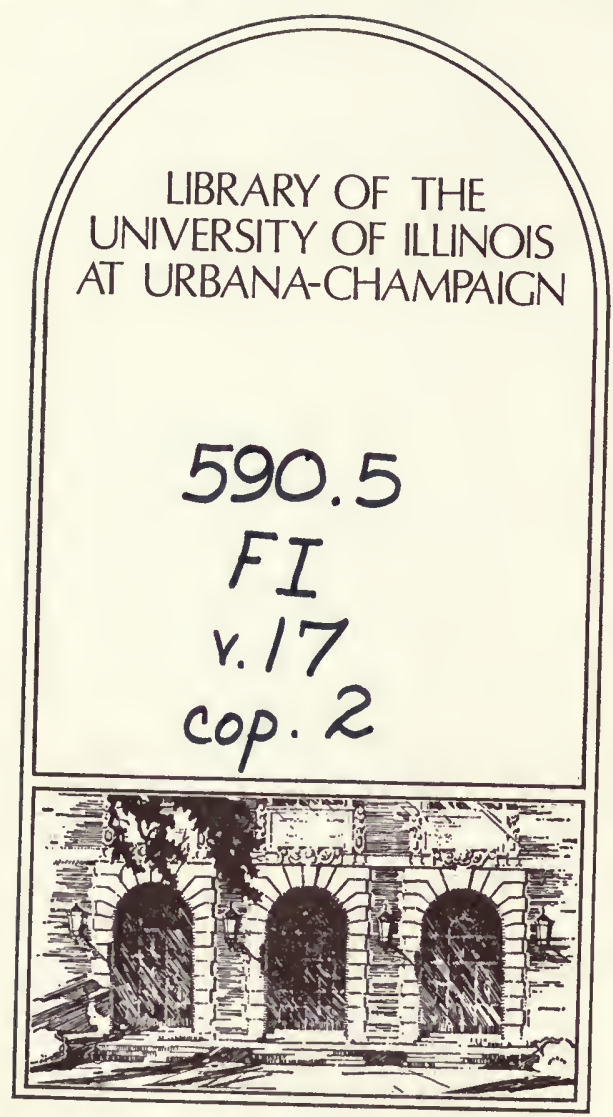




\section{CENTRAL CIRCULATION BOOKSTACKS}

The person charging this material is responsible for its renewal or its return to the library from which it was borrowed on or before the Latest Date stamped below. You may be charged a minimum fee of $\$ 75.00$ for each lost book.

Theft, mutiliatlon, and underlining of books are reasons for disciplinary action and may result in dismissal from the University.

TO RENEW CALL TELEPHONE CENTER, 333-8400

UNIVERSITY OF ILLINOIS LIBRARY AT URBANA-CHAMPAIGN

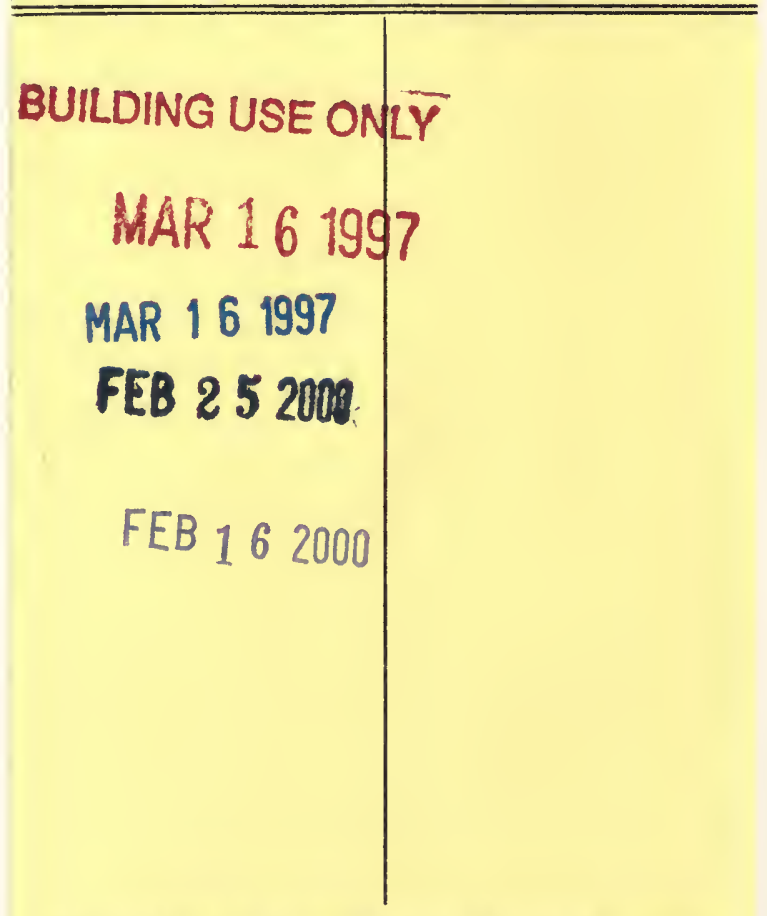

When renewing by phone, write new due date below previous due date.

L162 



17

D. 2 FieLd Museum of NatURal History

Founded by Marshall Field, 1893

PUBlication 257
ZOOLOGICAL SERIES
VoL. XVII, No. 1

\section{THE BIRDS OF THE NEOTROPICAL GENUS DECONYCHURA}

BY

JOHN T. ZIMMER

ASSISTANT CURATOR OF BIRDS

WILFRED H. OSGOOD CURATOR, DEPARTMENT OF ZOOLOGY EDITOR

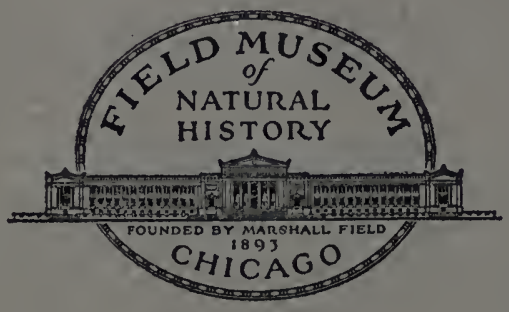

CHICAGO, U. S. A.

MAY 18,1929 



\title{
Field Museum of Natural History
}

Founded by Marshald Field, 1893

Publication 257

\section{THE BIRDS OF THE NEOTROPICAL GENUS DECONYCHURA}

\author{
BY \\ JOHN T. ZIMMER \\ ASSISTANT CURATOR OF BIRDS
}

WILFRED H. OSGOOD

CURATOR, DEPARTMENT OF ZOOLOGY

EDITOR

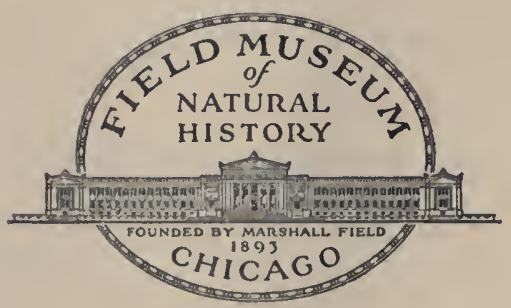

CHICAGO, U. S. A.

MAY 18,1929 
PRINTED IN THE UNITED STATES OF AMERICA

BY FIELD MUSEUM PRESS 


\section{THE BIRDS OF THE NEOTROPICAL GENUS DECONYCHURA}

BY JOHN T, ZIMMER

While studying the birds obtained by the Captain Marshall Field Peruvian Expedition of 1922-23 I have been interested to find that practically all records of Deconychura longicauda refer to males or to specimens of unknown sex. It also appears that, until recently, only two specimens of $D$. stictolaema have been recorded, one female (the type) and one not sexed. One example of each species was secured in 1923 at Puerto Bermúdez, Perú, and, curiously enough, that of longicauda was a male and that of stictolaema, a female. The possible interrelationship of these two forms therefore seemed worthy of investigation.

Thanks to the kindness of Mr. W. E. C. Todd of Carnegie Museum, Pittsburgh, and Dr. Frank M. Chapman of the American Museum of Natural History, New York, I have been able to borrow sufficient material to settle the point at issue. As might have been expected, the two species prove to be quite distinct, but, in the course of the investigation, other unsuspected relationships within the genus have become evident and three new races appear to be worthy of recognition. Since all the forms of the genus came under observation, it seems well to present a review of all the species and subspecies.

I am greatly indebted to Mr. Todd and Dr. Chapman for the loan of material used in this study, and further to Mr. Todd for permission to describe two new forms which were found only in the series belonging to Carnegie Museum.

\section{Genus DECONYCHURA Cherrie.}

Deconychura Cherrie, Proc. U. S. Nat. Mus., 14, p. 338, 1891-type Deconychura typica CHERRIE.

Dendrocinclopa ChuвB, Bull. Brit. Orn. Cl., 40, p. 107, 1920-type Dendracincla longicauda guianensis CHUBB.

Examination of the various forms of this genus induces the conclusion that all of them can be grouped under two specific heads, longicauda and stictolaema. These two species are distinguishable 
chiefly by the rufous rump and smaller size of stictolaema. Their general coloration is not greatly dissimilar, especially in certain western forms, although longicauda tends to be more heavily marked on the under surface. Both have a variable amount of rufescence on the upper scapular border of the wing (though it is oftener lacking in stictolaema), but the color of the rump appears to be quite constant and diagnostic.

Both species are found together over a wide area in the Amazonian lowlands, but longicauda passes farther northward into Colombia and Central America while stictolaema appears not to go beyond Ecuador, and there are some other differences at other extremities of their ranges. The distributions are not, therefore, completely parallel although racial distinctions occur in both groups at not far distant points.

The larger and more widely distributed species will be taken up first.

\section{Deconychura longicauda longicauda (Pelzeln).}

Dendrocincla longicauda Pelzeln, Orn. Bras., 1, pp. 42, 60, 1868-part, Marabitanas and Barra do Rio Negro (=Manáos); Sclater AND Salvin, P. Z. S. Lond., 1868, p. 54-Amazonia (part); idem, Nom. Av. Neot., p. 67, 1873- (ex Pelzeln, part); Salvin, Ibis, 1885, p. 421-Bartica Grove, Merumé Mts., British Guiana; RIdGway, Proc. U. S. Nat. Mus., 10, p. 496, "1887" = Jan., 1888-(ex Pelzeln, part); Sclater, Cat. B. Brit. Mus., 15, p. 165, 1890-part, Barra do Rio Negro, Surinam, Merumé Mts. and Bartica Grove, British Guiana; Oberholser, Proc. Acad. Nat. Sci. Phil., 56, p. 451, 1904-(ex Pelzeln, part).

Dendrocincla longicauda guianensis CHuBB, Bull. Brit. Orn. Cl., 39, p. 61, 1919-Bartica Grove, Brit. Guiana.

Deconychura longicauda HellmaYR, Nov. Zool., 14, p. 368, 1907-part, Bartica Grove, Merumé Mts., Brit. Guiana, and Marabitanas, Barra do Rio Negro, Brazil; idem, op. cit., 17, p. 334, 1910-part, Barra and Manáos; RIDGWAY, Bull. U. S. Nat. Mus., 50, pt. 4, p. 284, 1911-part, Brit. Guiana to Rio Negro; BeEBe, Trop. Wild Life, 1, p. 133, 1917-Bartica Grove; Hellmayr, Field Mus. Nat. Hist. Publ., Zool. Ser., 13, pt. 4, p. 363, 1925-part, Dutch and British Guiana, and northern Brazil (Manáos and Marabitanas; type loc. desig. Manáos).

Dendrocinclopa longicauda guianensis CHuBB, Birds. Brit. Guiana, 2, p. 120, 1921-Bartica Grove and Merumé Mts., Brit. Guiana.

Diagnosis.-Darker and deeper in coloration than pallida from south of the Amazon; pale streaking of anterior under parts deeper buff, more sharply defined. Similarly deeper colored than the western 
races (Perú to Costa Rica), though to a lesser degree, with the pectoral spots distinctly more linear and less sagittate or guttate.

Habitat.-The Guianas and Brazil north of the Amazon.

Description.--Top of the head dark Olive Brown ${ }^{1}$ to blackish Clove Brown, with narrow buffy shaft streaks; back about Bister, sometimes approaching Snuff Brown; upper tail coverts and extreme lower margin of rump light Bay; chin and throat light Tawny-Olive to Cinnamon-Buff, regularly though lightly margined with brown, the margins becoming broader on the lower portion of the throat; breast and sides deep Saccardo's Umber, with central shaft stripes of Tawny-Olive or Cinnamon-Buff; lores dusky whitish; auriculars Sepia with Cinnamon-Buff shaft lines; streaks of the breast continued down the middle of the belly as narrower hair lines, sometimes broadened a little toward the tips of the feathers to form indistinct spots; flanks Saccardo's Umber, unstreaked; under tail-coverts like the flanks but with a rufescent tinge at the tips of the longest feathers and withoccasional strong traces of central spots. Rectrices Bay, paler beneath with under side of shafts still lighter. Remiges light Chestnut with an olivaceous wash along the outer margin; five outer primaries with dull blackish tips; remainder of primaries and secondaries with an obscure dusky area along the shaft near the tip; scapular border of lesser upper wing-coverts suffused with Chestnut to a varying degree; rest of upper wing-coverts Brussels Brown with a chestnut tinge on the inner webs; under wing-coverts deep tawny Ochraceous-Buff. Sexes alike in color; female smaller in size. Wing, or 102-114 mm., 우 95-97.5; tail, ơ 96-115, ㅇ 92-99; exposed culmen, ơ 22-26, ㅇ 20-23; culmen from base, ơ 25-30, 우 23.5-27; tarsus, ơ 22-25.5, 우 20-22.5.

There are certain minor variants of the above details of coloration, but they are not capable of geographical apportionment. The lesser upper wing-coverts along the scapular border are but lightly rufescent in six specimens, a little stronger in seven, more prominently marked in eight, and quite rufescent in four. The specimens from French Guiana average more rufescent on the shoulder than do those from nearer the Amazon, but one of the Guianan birds is very lightly marked in this particular and two of the Obidos examples are among the prominently marked series. Since the reduction in intensity of the shoulder patch is characteristic of the race found south of the Amazon in Brazil, it is not strange that birds from just across the

"Names of colors when capitalized indicate direct comparison with Ridgway's "Color Standards and Color Nomenclature." 
river show a greater tendency in that direction than do examples from a more distant region.

Pelzeln described his longicauda from specimens secured by Natterer at Borba, Marabitanas, and Manáos, Brazil. Borba was generally accepted as type locality until Hellmayr (1925) pointed out that only one specimen, from Manáos, out of Natterer's original series, agreed in detail with Pelzeln's description, and that Manáos must, therefore, replace Borba as type locality. The matter is important since the forms found north and south of the lower Amazon prove to be different.

Chubb (1919) renamed the northern form guianensis on characters which he found in (two?) specimens from British Guiana, but he neglected to explain what he considered to be typical longicauda. Later (1921) he gave the range of guianensis as confined to British Guiana, evidently distinguishing it from the specimens taken in Surinam and at Manáos which were in the British Museum collection with his type. Hellmayr (1925) noted that British Guianan specimens (including Chubb's type of guianensis) were absolutely indistinguishable from Manáos specimens. A fine series of excellent skins in Carnegie Museum from French Guiana and from Obidos, Manacapurú, and Tonantins, Brazil, further show that the form found north of the Amazon in Brazil and the Guianas is indivisible. The Manacapurú specimens are nearly topotypical longicauda.

Deconychura longicauda pallida subsp. nov.

Dendrocincla longicauda Pelzeln, Orn. Bras., 1, pp. 42, 60, 1868-part, Borba, Rio Madeira; Sclater AND SAlvin, P. Z. S. Lond., 1868, p. 54Amazonia (part); idem, Nom. Av. Neot., p. 67, 1873-(ex Pelzeln, part); RIDGWAY, Proc. U. S. Nat. Mus., 10, p. 496, "1887"=Jan., $1888-(\mathrm{ex}$ Pelzeln, part); Sclater, Cat. B. Brit. Mus., 15, p. 165, 1890-Ega, Rio Solimões; OBerholser, Proc. Acad. Nat. Sci. Phil., 56, p. 451, $1904-$ (ex Pelzeln, part).

Deconychura longicauda HellmaYr, Nov. Zool., 14, pp. 367, 368, 1907-part, Borba; idem, op. cit., 17, p. 334, 1910-part, Calama, Rio Madeira; idem, Abhandl. Bayr. Ak. Wiss., Math.-phys. Kl., 26, No. 2, pp. 41, 92, 1912-Peixe-Boi, Pará); Snethlage, Bol. Mus. Goeldi, 8, p. 343, 1914Providencia, (Pará), Rio Iriri (Bocca do Curua); Hellmayr, Field Mus. Nat. Hist. Publ., Zool. Ser., 13, pt. 4, p. 363, 1925-part, Ega, Borba, Calama, Brazil, and Río San Mateo, n. Bolivia; Chapman, Bull. Am. Mus. Nat. Hist., 55, p. 461, 1926-part, Rio Roosevelt, Brazil.

Type from Hyutanahán, Rio Purús, Brazil. No. 86902 Carnegie Museum. Adult male. Collected December 31, 1921 by S. M. Klages. Original number 28304. 
Diagnosis.-Similar to D. l. longicauda from north of the Amazon (Manáos to the Guianas), but colors of body plumage paler; throat and spots of breast distinctly more yellowish buff, less orange-tinted; dark edges of the feathers on breast and crown paler olive, less dusky; feathers of throat less conspicuously edged with dusky; streaks on breast averaging narrower, less sharply defined; rufescent area on scapular border of upper wing-coverts averaging less prominent, sometimes nearly obsolete.

Habitat.-Brazil, south of the Amazon, and possibly lowlands of northern Bolivia.

Description of type.-Top of the head dark Olive Brown, with the feathers dusky on their edges and with narrow shaft lines of dull Pinkish Buff, broader on the lateral margins of the occiput and nape where they form a noticeable pale superciliary stripe; back light Snuff Brown, changing abruptly on the upper tail-coverts and the lowest margin of the rump to Kaiser Brown. Lores dusky white; auriculars, malar region, and sides of neck dusky Olive-Brown with buffy shaft streaks; chin and throat light Pinkish Buff; sides of lower throat with dusky olivaceous edges; breast light Saccardo's Umber, with obovate central shaft streaks of Pinkish Buff; belly and flanks paler, Buffy Brown, with occasional faint suggestions of shaft streaks; under tail-coverts anteriorly like the belly, posteriorly Hazel. Rectrices Bay, paler beneath and with under side of shafts still paler. Remiges bright Auburn with exterior margins washed with olive; tips of five or six outer primaries dull blackish; remainder of primaries and secondaries with a more or less obvious dusky area at tip; upper wing-coverts pale Saccardo's Umber, those along scapular edge of wing suffused with Hazel; under wing-coverts CinnamonBuff, brownish at the bend of the wing; inner margin of quills Pecan Brown. Wing, $105 \mathrm{~mm}$.; tail, 99; exposed culmen, 26; culmen from base, 29.5; tarsus, 23.

Females similar but smaller. Range of measurements in both sexes as follows: wing, o $\sigma^{7}$ 104-109 mm., क 96-99; tail, or 95-104, ㅇ 88.5-104; exposed culmen, $\sigma^{7}$ 25-27, o $21.5-23$; culmen from base, ơ 28.5-31, 우 25-27; tarsus, ơ 22-24.5, ㅇ 21-22.5.

As in typical longicauda there is considerable individual variation within the limits of the racial characteristics. One male from the type locality appears to be slightly immature, judging by the texture of the abdominal feathers. The upper belly and hind neck in this specimen are inclined to be broadly, but obscurely, spotted with 
pale buffy white, margined, equally obscurely, with dusky. In normal plumage the belly is unspotted and the nape is less spotted than streaked. In five specimens there are only slight traces of the rufescent patch on the scapular border of the wing; there is a little more in eight others (including the type), but none of the series is as strongly marked as are most specimens from north of the Amazon.

Three specimens from São Paulo de Olivença, Rio Solimões, are somewhat intermediate between pallida and longicauda but show no tendency toward the characters of the Peruvian form next to be described. All three have a slight suggestion of immaturity in the texture of the plumage and immaturity may possibly account for the differences observed. They are not very different from two other males, one from Villa Braga, Rio Tapajóz, and one from Nova Olinda, Rio Purús, and may, after all, represent only the extreme variants of pallida. They are slightly deeper buff on the pale portions of the ventral plumage than typical pallida but are paler and less sharply marked than longicauda. There is very little rufescence on the shoulder of any of them.

Three examples from the Pará district (Colonia de Mojuy, Santarem, and Benevides, Bragança R. R.) present a somewhat different problem. These birds may prove to be separable from pallida from which they differ by having the markings of the throat and chest even less buffy. The Santarem specimen is not so different from some of the palest Purús and Tapajóz examples but the female from Benevides is much grayer on the belly and whiter on the throat while the ventral streaking is more linear than in any of the series of true pallida. The male from Benevides is intermediate. In any case, without a larger series from the Pará region, it is unwise to attempt the separation of another race on the differences noted. All three of these specimens have only a little rufescence on the shoulder.

The record from Río San Mateo, northern Bolivia, given by Hellmayr (1926), is based on a specimen in the Berlepsch collection. Without examining this specimen in the light of recent observations, it is impossible to say without doubt that it belongs to pallida and not to some other form, known or unknown. From the geographical position of the locality it is more likely to belong with pallida than with the Peruvian race.

Deconychura longicauda connectens subsp. nov.

Deconychura longicauda HellmaYr, Field Mus. Nat. Hist. Publ., Zool. Ser., 13, pt. 4, p. 363, 1925-part, Puerto Bermúdez, Peru; Chapman, Bull. 
Am. Mus. Nat. Hist., 55, p. 461, 1926-part, Sabanilla and Macas, e. Ecuador.

Type from Puerto Bermúdez, Rio Pichis, Dept. Junin, Peru. Altitude 1100 feet. No. 65866 Field Museum of Natural History. Adult male. Collected March 17, 1923 by J. T. Zimmer. Original number 3514.

Diagnosis.-Similar to D. l. typica from Costa Rica, but averaging larger in all dimensions. Top of the head with shaft streaks broader; ventral pattern similar but belly more olivaceous, less grayish; pale centers of pectoral feathers a little narrower and less sharply bordered with more olivaceous (less blackish) margins.

From $D$. l. longicauda it is separable by the paler, less ochreous throat; the pectoral feathers with their centers paler and less ochreous but more sharply defined by the dusky edges, leaving the shaft spots broader and more sagittate than the more deeply colored linear streaks of longicauda.

From D. l. pallida it is separable by the deeper general coloration, with the throat somewhat deeper buff while the wings and tail are about the same in both forms; breast feathers more heavily margined with more dusky olive; belly deeper olive; pectoral spots more sharply defined and less linear; back deeper brown.

Habitat.-Tropical zone of eastern Perú and southeastern Ecuador.

Description of type.-Back Brussels Brown $\mathrm{x}$ Raw Umber, changing abruptly to Chestnut on the very lowermost rump feathers and the upper tail-coverts; top of the head Brussels Brown x Mummy Brown with relatively narrow shaft streaks of deep Clay Color, present also on the hind neck but disappearing on the mantle; streaks on the lateral borders of the head broader, forming a rather pronounced buffy superciliary stripe on each side. Lores white with a faint buffy tinge; auriculars mostly whitish buff with narrow, dusky brown edges; chin and upper throat whitish with a faint buffy tinge and with narrow, buffy brown edges, not sharply defined; malar region and lower throat dull, pale Cinnamon-Buff with dusky olive brown margins and tips; breast with sagittate central spots of Cinnamon-Buff, edged with dark Saccardo's Umber; sides of neck similar but central areas not so sharply defined; sides of breast similar to middle but with shaft spots somewhat more linear though retaining a broadened area near the tip which continues the spotted appearance; lower breast with gradually reducing shaft spots which are 


\section{Field Museum of Natural History-Zoology, Vol. XVII}

continued faintly down the middle of the upper belly; flanks and thighs Saccardo's Umber without pale markings; under tail-coverts with anterior portion Saccardo's Umber, changing to Kaiser Brown or pale Chestnut on the terminal portion. Rectrices Bay, paler beneath and with under side of shafts still paler. Remiges light Chestnut with an olivaceous wash along the outer margin; five outer primaries with dull blackish tips; remainder of primaries and secondaries with a rather obscure dusky area along the shaft near the tip; upper wing-coverts Brussels Brown with a Chestnut tinge on the inner webs; lesser coverts along the scapular border distinctly though not strongly Chestnut in tone; under wing-coverts deep tawny Ochraceous-Buff; bend of wing beneath Brussels Brown; inner margin of quills Cacao Brown. Iris brown; bill with maxilla mostly brown, blackish at the base, and mandible olive green; feet bluish slate. Wing, $102 \mathrm{~mm}$.; tail, 102; exposed culmen, 25; culmen from base, 30; tarsus, 22 .

Two specimens from Sabanilla, Río Zamora, and Cutucuo, Macas region, eastern Ecuador, show the same general features as the type, with a closer approach toward typica in coloration though not in size. The Sabanilla bird (a male in molt) especially is very similar to a specimen of typica from Palmar, Costa Rica, being more grayish olive and less rufescent on the breast and belly than the type of connectens, with the pectoral spots paler ochraceous. The Cutucuo specimen (of undetermined sex) is more dusky below than either of the others, with the dusky margins of the feathers of breast and sides rather darker; the back also is darker, being Raw Umber, with faint blackish tips; the top of the head is duskier with the shaft streaks narrower; the entire mid belly is spotted broadly like the breast but the dark edges are less dusky and more pale olivaceous, giving the mid belly a distinctly pale median area. The under wing-coverts are quite pale in the Cutucuo bird in comparison with the deep buff of the type, but in the Sabanilla specimen the color is very little lighter than in the bird from Perú. Both Ecuadorian skins are larger than the type, thus differing even more from typica in that regard. The first of each pair of the following measurements refers to the Sabanilla specimen; the second, to the Cutucuo specimen. Wing, 108, 106; tail 101 (imperfect), 109; exposed culmen, 22.5, 23.5; culmen from base, 26.5, 29; tarsus, 23, 24.5.

If these Ecuadorian birds belong to the Peruvian race, connectens, as I believe, this race is somewhat more variable than the others and, while recognizable in itself, exhibits certain characteristics of 
the other forms between which it is the connecting link. Curiously enough, although it is no ornithological novelty, its closest affinities are not with the immediately adjacent forms but with those once removed. Actually it is closest to typica from which it is separated not only by its subspecific characters but also by the intervention of the Colombian race, minor.

\section{Deconychura longicauda minor Todd.}

Deconychura typisa minor TodD, Proc. Biol. Soc. Wash., 32, p. 116, June 27, 1919-El Tambor, Santander, Colombia; Hellmayr, Field Mus. Nat. Hist. Publ., Zool. Ser., 13, pt. 4, p. 362, 1925-El Tambor.

Diagnosis.-Similar to $D . ' l$. typica from Costa Rica but upper parts more olivaceous and less rufescent; lores and auriculars whiter, less buffy; pale markings of under parts lighter and more restricted; size possibly smaller.

From connectens of Perú and Ecuador it is distinguishable by a still greater difference in size; pale shaft streaks on the crown narrower; general coloration paler except that the dusky margins of the pectoral feathers are darker in contrast to the much lighter central spots.

From longicauda and pallida it is distinguishable by having the chest more dusky with broad central spots, whereas in the other two forms the pectoral marking is linear, with the margins uniform with the sides and flanks.

Habitat.-Known only from the type locality, but possibly ocçurring in other parts of central Colombia.

Description.-Back dark Buffy Brown, changing abruptly to Kaiser Brown $x$ Chestnut on the upper tail-coverts and adjacent margin of the rump; top of the head dark Olive-Brown with buffy shaft lines not very strongly marked. Lores whitish; auricular and malar regions whitish buff edged with dusky; throat buffy Isabella Color with dusky brown margins on at least the lateral feathers; chest dark Olive-Brown or blackish brown at the tips of the feathers, with broad, rounded central spots of Cartridge Buff x Cream-Buff; lower breast somewhat paler and more uniform, with the central spots indistinct, not sharply defined; belly and flanks Light Brownish Olive or Brownish Olive; under tail-coverts anteriorly like belly, Hazel at tip. Rectrices light Bay, paler beneath and with under side of shafts still paler. Remiges light Bay; upper wing-coverts a trifle browner; lesser upper coverts along scapular border rufescent; under wing-coverts Ochraceous-Buff. Female similar but smaller. Wing, 
o 92 mm., ㅇ 88; tail, ơ 89, ๆ 86; exposed culmen, ơ 21, 우 19; culmen from base, $\sigma^{\top} 24$, $q 21.5$; tarsus $\sigma^{\pi} 22$, +20 .

This race, instead of being intermediate between typica and connectens in taxonomic characters, as it is geographically, is a small, pale extreme, unlike either although nearer to them than it is to longicauda or pallida. It is closest to typica, having the dusky pectoral area spotted with paler color as in that form. The type may be slightly immature, judging by the texture of the feathers.

\section{Deconychura longicauda typica Cherrie.}

Deconychura typica Cherrie, Proc. U. S. Nat. Mus., 14, p. 339, 1891-Pozo Azul de Pirris, s.w. Costa Rica; idem, Expl. Zool. Merid. Costa Rica, p. 39, 1893-Palmar, s.w. Costa Rica; idem, Anal. Inst. Fis.-Geog. Costa Rica, 6, p. 17, 1893-Pozo de Pital, s.w. Costa Rica (descr. nest and eggs); Bangs, Auk, 18, p. 367, 1901-Divala, Chiriquí, Panamá; SharPe, Handlist, 3, p. 77, 1901-Costa Rica to Panamá; Hellmayr, Nov. Zool., 14, p. 368, 1907-Costa Rica and Chiriquí (diag.); CARrIKer, Ann. Car. Mus., 6, p. 652, 1910-Pozo Pital, Pozo Azul de Pirrís, El General de Terraba, El Pozo de Terraba, s.w. Costa Rica; RIDGway, Bull. U. S. Nat. Mus., 50, pt. 4, p. 285, 1911-\$.w. Costa Rica and Panamá.

Deconychura typica typica Hellmayr, Field Mus. Nat. Hist. Publ., Zool. Ser., 13, pt. 4, p. 361, 1925-s.w. Costa Rica and w. Panamá.

? Dechonychura typica minor Griscom, Am. Mus. Novit., 293, p. 1, 1928-n. Chiriquí, Panamá.

Diagnosis.-Similar to D. l. longicauda but smaller; feathers of chest with more blackish margins and more sagittate, less linear, pale central areas; belly paler.

From minor it is distinguishable by its more rufescent upper parts and its more extended and deeper buff markings on the chest.

From connectens it is separable by smaller size, darker margins on the feathers of the chest, more buffy throat, narrower shaft streaks on the top of the head, paler belly, and slightly more rufescent back.

Habitat.-Southwestern Costa Rica and western Panamá.

Description.-Top of head Clove Brown with hair streaks of Pinkish Buff along the shafts; back Brussels Brown, changing abruptly to Chestnut on the upper tail-coverts and extreme lower border of the rump. Lores dusky white, faintly tinged with buff; a narrow superciliary line light Pinkish Buff; malar region and auriculars dull Cinnamon-Buff with dusky margins; chin and throat light Pinkish Buff with traces of dusky tips; feathers of upper breast with sagittate central spots of light Cinnamon-Buff, margined and tipped with blackish Clove Brown, blacker on the central feathers, more olivaceous on the lateral ones; lower breast, sides and flanks Buffy 
Brown with indistinct shaft spots of pale buff becoming obsolete on the belly and lower flanks; anterior under tail-coverts like the belly, posterior ones Chestnut $\mathrm{x}$ Auburn. Rectrices Bay $\mathrm{x}$ Chestnut, paler beneath and with under side of shafts still paler. Remiges light Chestnut with an olivaceous tinge along the outer margin, especially toward the base; five or six outer primaries with dusky brown tips; remainder of primaries and secondaries with an indistinct darker subterminal area; upper wing-coverts mostly Snuff Brown, more rufescent on the inner webs; the lesser coverts at the scapular border distinctly Hazel; under wing-coverts deep tawny OchraceousBuff with bend of wing a little browner; inner margin of quills Army Brown. Measurements (including those by Ridgway, 1911) as follows: wing, or 94-102 mm., ㅇ 86-90; tail, ơ 89.5-96, 83.5-88; exposed culmen, $\sigma^{7} 19.5-23$, $\circ$ 20-21.5; culmen from base, $\sigma^{7} 25$, ㅇ 23; tarsus, ơ 20.5-22, 우 19-20.

The above description is drawn up from a specimen collected by Cherrie at Palmar, Costa Rica. Other specimens examined vary in the direction of more rufescent upper parts, blacker margins on the feathers of the chest, deeper buff throat, and darker, more spotted belly.

Deconychura stictolaema stictolaema (Pelzeln).

Sittasomus stictolaemus Pelzeln, Orn. Bras., 1, pp. 42, 59, 1868-Borba, Rio Madeira; Sclater AND Salvin, Nom. Av. Neot., p. 66, 1873-Amaz. sup.; Sclater, Cat. B. Brit. Mus., 15, p. 120, 1890-part, Amazonia (part, ex Pelzeln).

Deconychura stictolaemus Hellmayr, Nov. Zool., 14, p. 368, 1907-Borba.

Deconychura stictolaema Hellmayr, Nov. Zool., 17, p. 333, 1910-Borba; Snethlage, Bol. Mus. Goeldi, 8, p. 343, 1914-Rio Madeira; Hellmayr, Field Mus. Nat. Hist. Publ., Zool. Ser., 13, pt. 4, p. 362, 1925-part, Borba.

Diagnosis.-More olivaceous in tone than the other races, with paler buffy markings below; top of the head browner (less blackish) than in clarior from north of the Amazon.

Habitat.-Amazonian lowlands of eastern Brazil, south of the Amazon and west at least as far as the Rio Tapajóz.

Description.-Top of the head Clove Brown with buffy shaft lines, obsolete on the nape; mantle light Bister; lower back, rump, and upper tail-coverts light Chestnut. Lores whitish with dusky tips immediately before the eye; shaft streaks of crown wider on lateral borders, forming a pale superciliary line on each side; auriculars dusky brown with pale shaft lines; malar region with shaft 


\section{Field Museum of Natural History-Zoology, Vol. XVII}

marks broader, more ovate; chin and throat light Olive-Buff with light Olive Brown margins and tips which are continued, darker and heavier, on the upper breast, leaving sagittate central spots of buff; belly and flanks Buffy Brown or Saccardo's Umber; sides like breast but with pale central spots reduced to shaft lines; flanks Brownish Olive x Light Brownish Olive; mid belly dark Isabella Color; under tail-coverts like belly on their upper portion, dark Cinnamon-Rufous on the lower part. Rectrices deep Chestnut above, light Russet below, with Apricot Buff shafts. Remiges fuscous; outer webs of primaries and secondaries Snuff Brown x Saccardo's Umber, becoming more rufescent toward the tips of the inner secondaries; tertials Auburn x Chestnut; upper wing-coverts Dresden Brown with a concealed area of bright Hazel (sometimes absent) along the scapular border; under wing-coverts Cinnamon-Buff. Wing, ot 86-87 mm.; tail, 82-89; exposed culmen, 16-17.5; culmen from base, 20-22; tarsus, 19-20.5.

The rufous patch on the shoulder is well marked in a specimen from Colonia de Mojuy, Santarem, Pará, is present but not conspicuous in a Miritituba example, and is totally absent in a Villa Braga bird. The type is described by Hellmayr (1907) as having the shoulder olive brown, apparently without rufous.

Deconychura stictolaema clarior subsp. nov.

Type from Pied Saut, Oyapock, French Guiana. No. 68183 Carnegie Museum. Adult male. Collected April 1, 1918 by S. M. Klages. Original number 16438.

Diagnosis.- Top of the head a little blacker than in stictolaema; back somewhat more rufescent and very slightly less dusky; rump and upper tail-coverts distinctly lighter rufous; pale areas of head and under parts decidedly more buffy with the belly altogether paler; rectrices and tertials rather lighter rufescent; under tailcoverts more extensively but paler rufescent.

Description of type.-Top of the head Chaetura Black with narrow shaft streaks of pale buff, becoming obsolete on the nape or at least not as sharply defined; mantle Snuff Brown; lower back, rump, and upper tail-coverts bright Hazel. Lores dull whitish with dusky tips immediately in front of the eye; the pale shaft streaks of crown broader above the eye, forming a superciliary stripe of TawnyOlive; auriculars like the crown; malar region with the Tawny-Olive shaft streaks broader than the dark brown edges; chin and throat 
pale Clay Color with tips of Saccardo's Umber; the dark tips on the chest broader and the color of the central spots deeper, rich TawnyOlive; sides like breast; flanks Saccardo's Umber x Tawny-Olive, with paler shaft stripes ill-defined; center of belly clear TawnyOlive; basal under tail-coverts like belly; longer ones, embracing the distal two-thirds of the area, Sanford's Brown x CinnamonRufous. Rectrices light Chestnut above, Hazel $\mathrm{x}$ light Russet below, with shafts Apricot Buff. Remiges fuscous; outer webs of primaries and secondaries Snuff Brown x Saccardo's Umber, becoming more rufescent toward the tips of the inner secondaries; tertials largely Chestnut $\mathrm{x}$ Auburn except at base of outer webs where the color is nearer Snuff Brown; upper wing-coverts Dresden Brown with a concealed area of variable intensity along the scapular border bright Hazel; under wing-coverts Cinnamon-Buff, more grayish at base of primaries. Wing, $87 \mathrm{~mm}$.; tail, 89; exposed culmen, 16; culmen from base, 19; tarsus, 21.

Female like the male but smaller.

The series examined is rather consistent in coloration. One specimen from the type locality is somewhat darker below than the others, with a more olivaceous tone on the flanks, but it is still more rufescent than typical stictolaema. The color of the tail varies a little in the direction of a paler tone. The rufous shoulder patch is well marked in six specimens (including the type), inconspicuously present in two, barely suggested in one immature example, and absent in another young bird. The variation in size is as follows: wing, or 86-90.5 mm., ㅇ 75 (-79); tail, o $\sigma^{7} 88-95.5$, ㅇ 75 (-81); exposed culmen, $\sigma^{7} 15-16.5$, \& 15 ; culmen from base, or 19-21, ㅇ 19; tarsus, $\sigma^{7}$ 20.5-22, ᄋ $18.5(-19)$. The measurements in parentheses are those of a specimen the sex of which is in doubt; it is marked as a male but probably is a female.

\section{Deconychura stictolaema secunda Hellmayr.}

Sittasomus stictolaemus Sclater AND SAlvin, P. Z. S. Lond., 1873, p. 270Chamicuros, Perú; Taczanowski, Orn. Pér., 2, p. 164, 1884-Chamicuros; SClAter, Cat. B. Brit. Mus., 15, p. 120, 1890-Amazonia (part, Ucayali).

Deconychura secunda Hellmayr, Bull. B. O. C., 14, p. 51, 1904-Coca R., upper Río Napo, Ecuador (" $\subsetneq "=\sigma^{7}$ ?); idem, Nov. Zool., 14, p. 368, 1907-Coca; idem, Field Mus. Hat. Hist. Publ., Zool. Ser., 13, pt. 4, p. 362, 1925-Coca; Chapman, Bull. Am. Mus. Nat. Hist., 55, p. 462, 1926 -(ex Hellmayr 1904).

Dendrocincla sp. inc. Goodfellow, Ibis, 1902, p. 62-Coca. 


\section{Field Museum of Natural History-Zoology, Vol. XVII}

Deconychura stictolaema Hellmayr, Field Mus. Nat. Hist. Publ., Zool. Ser., 13, pt. 4, p. 362-part, Puerto Bermúdez and Chamicuros, Perú.

Diagnosis.-Similar to $D$. s. stictolaema but back less rufescent brown; under surface more olivaceous; buff spotting on the chest more distinct; wings and tail deeper rufous; shoulder patch less pronounced or more often absent.

Separable from clarior by the browner (less blackish) top of the head; back duller, less rufescent; rump deeper rufous; under parts more olivaceous; pale portions of throat and chest less buffy, more olive whitish.

Habitat.-Lowlands of northeastern Perú, eastern Ecuador, and extreme western Brazil (São Paulo de Olivença).

Description.-Top of the head Clove Brown with buffy shaft lines, obsolete on the nape; back light Sepia; lower back, rump, and upper tail-coverts light Bay. Lores whitish; pale shaft lines of sides of crown forming a narrow buffy superciliary line; sides of head as in stictolaema; chin and throat Pale Olive-Buff with tips and margins of the feathers Brownish Olive, broadest on the upper chest but narrowing to mere shaft lines on the lower breast and sides; flanks clear light Brownish Olive; mid belly a little lighter; under tailcoverts like the belly with only the tips of the longest coverts dark Hazel x Auburn. Rectrices deep Bay above, light Chestnut-Brown below, with shafts dull Salmon Color. Remiges as in stictolaema but darker; tertials Chestnut x Bay; under wing-coverts Pinkish Buff. Wing, $\sigma^{7} 84.5-88 \mathrm{~mm}$. (including Hellmayr's measurements of the type), ㅇ 76.5; tail, or 90, ㅇ 77; exposed culmen, or 19-20, 우 15.5; culmen from base, $\sigma^{7} 25$, ㅇ 20 ; tarsus, $\sigma^{7} 21$, ㅇ 19 .

It is with very slight misgivings that I have identified one Peruvian and one west-Brazilian specimen with Hellmayr's Deconychura secunda. It is evident from the original description of the rufous rump and the non-rufous shoulder that secunda is more closely allied to stictolaema than to longicauda with which it was originally compared. On the other hand, the differences from stictolaema as given by Hellmayr (1907) are exactly those which distinguish my Peruvian specimen from two undoubted stictolaema taken on the Rio Tapajóz. The specific distinctness of secunda from stictolaema depends, therefore, solely on the measurements. If the type specimen is a female, as indicated on the label (fide Hellmayr), secunda might exist as a still different race of stictolaema, separable by its much larger size. If the specimen is wrongly sexed, it is a perfectly normal 
male comparable in size to those of the other races. Since the sexes of the various forms of Deconychura are alike in color and since Goodfellow collected only one specimen of that genus (the type of secunda), the chances are extremely great that he made an error in determining the sex of that specimen, an error which afterward led to the description of secunda as a distinct species.

The São Paulo de Olivença bird is similar above to the Peruvian specimen, though with slightly greater rufescence on the mid back; below it is a little paler, with the throat and breast slightly buffier Light Brownish Olive; the belly is pale Buffy Brown; the wings and tail are of the same deep Bay and the other characters likewise are the same. There is no trace of rufescence on the scapular border of the wing in either specimen, in which both agree with the original description of secunda. Quite possibly the complete absence of rufescence on the shoulder is a constant character in this race, though variable in the others.

\section{Deconychura stictolaema var?}

Two skins from Arimã, right bank of the lower Purús, Brazil, are puzzling. Both are labeled as females although one, judging by its size, is probably a male. These specimens do not agree exactly with stictolaema, clarior, or secunda. The upper back is Verona Brown, more rufescent than any of the others; top of the head dark Olive-Brown with buffy shaft lines disappearing on the nape, the whole being paler than in the other races; color beneath about as in clarior but the under tail-coverts with rufescence only on the longer distal feathers, about as in secunda; rump and upper tail-coverts in one specimen a little darker than in secunda, in the other about as in clarior; rectrices and tertials of one example deep Bay as in secunda, of the other light Chestnut as in clarior; shoulder without rufescence.

Geographically, these birds should belong to typical stictolaema; taxonomically they are closer to clarior and secunda. Until more material is available from this particular region it is best to leave their subspecific assignment in abeyance.

Specimens examined (in Carnegie Museum unless otherwise specified).

D. l. longicauda-Brazil: Manacapurú, Rio Solimões (nearly topotypical) $2 \sigma^{7} \sigma^{7}$; Tonantins, Rio Solimões $2 \sigma^{7} \sigma^{7}$; Obidos, Pará $2 \sigma^{7} \sigma^{7} ; 1$ “ $\% "=\sigma^{x}$ ?. French Guiana: Pied 
Saut, Oyapock $9 \sigma^{x} \sigma^{x} 3$ 우 ; Tamanoir, Mana R. $30^{x} \sigma^{x}$ 2 우 울 Cayenne 1 ㅇ․

D. l. pallida-Brazil: Hyutanahán, Rio Purús $5 \sigma^{\top} \sigma^{7}$ (incl. type) 1 "위" = ㅇ ?; Nova Olinda, Rio Purús 1 ơ ; Arimã, Rio Purús $2 \sigma^{\top} \sigma^{\top} 1$ \% ; Villa Braga, Rio Tapajóz 1 \% 1

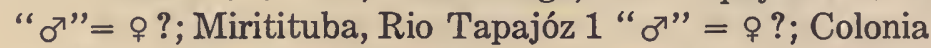
de Mojuy, Santarem, Pará $1 \sigma^{7}$; Benevides, Bragança R.R., Pará 1 ơ 1 \% ; São Paulo de Olivença, Rio Solimões 2 o $^{\top} \sigma^{\top} 1$ ㅇ.

D. l. connectens-Perú: Puerto Bermúdez $1 \sigma^{\top}$ (type). ${ }^{1}$ Ecuador: Sabanilla, Río Zamora, Prov. Loja $1 o^{x} ;$ Cutucuo, Macas region 1 ?. ${ }^{2}$

D. l. minor-Colombia: El Tambor, Santander $10^{7}$ (type) 1 우

D. l. typica-Costa Rica: Palmar $10^{7} ; 1$ El Pozo de Terraba 1 ơ $^{\top} 1$ ㅇ.

D. s. stictolaema-Brazil: Villa Braga, Rio Tapajóz 1 ơ; Miritituba, Rio Tapajóz $1 \sigma^{x}$; Colonia de Mojuy, Santarem, Pará $10^{\top}$.

D. s. clarior-French Guiana: Pied Saut, Oyapock $3 \sigma^{7} \sigma^{7}$ (incl. type); Tamanoir, Mana R. $3 \sigma^{\top} \sigma^{7}$. Brazil: Cayari Is., Uassa Swamp 1 ơ $^{7}$ " “ơ" = ㅇ ?; Obidos, Pará 1 ơ $^{7} 1$ ㅇ.

D. s. secunda-Perú: Puerto Bermúdez 1 ๆ.1 Brazil: São Paulo de Olivença, Rio Solimões $1 \sigma^{7}$.

D. stictolaema var?-Brazil: Arimã, Rio Purús 1 \% $1^{\prime \prime} q^{\prime \prime}=\sigma^{7}$ ?

Note.-Since the above account was put in type, a new race of $D$. longicauda has been described from Darién, Panamá, as D. typica darienensis Griscom, Bull. Mus. Comp. Zool., 69, p. 172, April 1929. Without having examined the type and only specimen of this race it is impossible to speak with absolute certainty, but I suspect that a series from eastern Panamá would show a considerable lessening of the ascribed differences from typica. The blackish borders and deep buff central spots of the throat and chest are characters of typica, the amount of rufescence on the shoulder is a variable feature, and while the size is somewhat smaller than recorded for typica the difference is slight in such a variable species. The fact that specimens from Almirante, w. Panamá, were identified as minor (Griscom, Am. Mus. Novit., 293, p. 1, 1928), indicates the extreme variability of the group in Panamá as elsewhere.

'Specimen in Field Museum of Natural History, Chicago.

'Specimen in American Museum of Natural History, New York. 









